\title{
PEMBELAJARAN PENDIDIKAN AGAMA ISLAM (PAI) BERBASIS MULTIKULTURAL
}

\begin{abstract}
Abstrak
Irma Novayani

Dosen Sekolah Tinggi Ilmu Tarbiyah (STIT) Al-Aziziyah Lombok Barat NTB

Pendidikan multikultural adalah sebuah sistem pendidikan yang berupaya untuk meredam kesenjangan sosial, kelas sosial, kecemburuan sosial dengan mengenalkan dan mensosialisasikan salah satu orientasinya yakni kebersamaan. Oleh karena itu dalam lembaga pendidikan Islam perlu menerapkan sistem pengajaran yang berorientasi pada penanaman kesadaran pluralisme dalam kehidupan. Adapun beberapa program pendidikan yang sangat strategis dalam menumbuhkan kesadaran pluralisme adalah: pendidikan sekolah harus membekali para mahasiswa atau peserta didik dengan kerangka (frame work) yang memungkinkannya menyusun dan memahami pengetahuan yang diperoleh dari lingkunganya.

Gagasan mengenai multikultural bukanlah sesuatu yang sulit, karena di dalam agama Islam mengajarakan tentang saling menghormati dan mengakui kebaradaan orang lain. perbedaan warna kulit, bahasa, dan budaya harus diterima sebagai sesuatu yang positif dan merupakan tanda-tanda dari kebesaran Allah SWT. Untuk itu sikap yang diperlukan bagi seorang muslim dalam merespon kemajemukan dan perbedaan adalah dengan memandangnya secara positif.
\end{abstract}

Kata Kunci: Pendidikan Agama Islam, Multikultural 


\section{PENDAHULUAN}

Indonesia adalah negara besar. Luas wilayahnya $\pm 1.919 .440 \mathrm{~km}^{2}$, dikelilingi oleh \pm 20 ribu pulau besar dan kecil, dan dihuni oleh \pm 238 juta jiwa penduduk dari beragam suku, agama, budaya dan kepercayaan. Dengan demikian, Indonesia melebihi kebanyakan Negara-negara lain merupakan negara yang multi suku, multi etnik, multi agama, dan multi budaya. Multicultural tersebut pada satu sisi merupakan kekuatan sosial dan keragaman yang indah apabila satu dengan lainnya bersinergi dan saling bekerja sama untuk membangun bangsa. Akan tetapi, keragaman bisa menjadi pemicu konflik dan kekerasan yang dapat menggoyahkan sendi-sendi kehidupan berbangsa dan bernegara apabila tidak dikelola dengan tepat dan baik.

Persoalan nilai pluralisme dan multikulturalisme merupakan tantangan utama yang dihadapi oleh agama-agama di dunia sekarang ini, mengingat setiap agama sesungguhnya muncul dari lingkungan keagamaan dan kebudayaan yang plural. Pada saat yang sama, para pemeluk agama-agama telah membentuk wawasan keagamaan mereka yang eksklusif dan bertentangan dengan semangat pluralisme dan multikulturalisme. Berbagai gerakan sering muncul dan sering menjadi sebab timbulnya wawasan dan perkembangan keagamaan baru. Dalam sejarah agama disebutkan bahwa pembaharu Budha muncul di tengah-tengah pandangan plural dari kaum Brahmais, Jaina, matrealistis, dan agnostis. Muhammad juga muncul di tengah-tengah masyarakat Mekah yang beragama terdiri dari komunitas Yahudi, Kristiani, Zoroaster, dan lainnya. Ibrahim dan Musa muncul dari lingkungan masyarakat yang menyembah berbagai macam dewa lokal. Munculnya piagam Madina misalnya, merupakan alat yang menjembatani betapa pluralnya masyarakat pada saat itu. Ini adalah salah satu bentuk sikap Islam terhadap munculnya multikulturalisme di tengah-tengah peradaban masyarakat. ${ }^{1}$

Salah satu tujuan pendidikan tidak mengenal kelas sosial. ${ }^{2}$ Kemasyarakatan, karena pendidikan multikultural adalah sebuah sistem pendidikan yang berupaya

\footnotetext{
${ }^{1} \mathrm{Ja}$ 'far Nashir. Respon Islam Terhadap Multikulturalisme. Diakses melalui situs http://nashir6768.multiply.com/journal/item/1?\&show_interstitial=1\&u=\%2Fjournal\%2Fitem,

${ }^{2}$ Kelas sosial adalah suatu strata (Lapisan) orang-orang yang berkedudukan satu dalam kontinum (rangkai kesatuan) status sosial. Sudjangi, Pluralitas sosial, hubungan antar kelompok
} 
untuk meredam kesenjangan sosial, kelas sosial, kecemburuan sosial dengan mengenalkan dan mensosialisasikan salah satu orientasinya yakni kebersamaan. Orientasi kebersamaan ini paling tidak akan mampu untuk memahami betapa sangat vitalnya menghargai dan menciptakan kebersamaan. Jika kelas sosial masih saja di agung-agungkan maka akan timbul kecemburuan sosial. Selama ini kecemburuan sosial sering terjadi di dunia pendidikan khususnya dalam upaya pembenahan sebuah sistem yang akan digunakan dalam rangka pengembangan model pendidikan tersebut. Pendidikan yang selama ini diwacanakan diberbagai aktifitas itu adalah pendidikan pada taraf teoritik. Pendidikan yang sebenarnya adalah pendidikan yang mampu mengenal, mampu mengakomodir segala kemungkinan, memahami heterogenitas. ${ }^{3}$ Menghargai perbedaan baik suku, bangsa, terlebih lagi agama.

\section{LANDASAN TEORI}

\section{Hakikat Multiculturalisme dan Pendidikan Multikultural}

Pendidikan multikultural membantu siswa mengerti, menerima, dan menghargai orang dari suku, budaya, nilai, dan agama berbeda sehingga tumbuh sikap saling menghargai perbedaan (agree in disagreement), dan dapat hidup saling berdampingan satu dengan yang lain (to live together). Dengan kata yang lain, siswa diajak untuk menghargai bahkan menjunjung tinggi pluralitas dan heterogenitas. Menurut Syafiq A. Mughni (2003: IX), paradigma pendidikan multikultural mengisyaratkan bahwa individu siswa belajar bersama dengan individu lain dalam suasana saling menghormati, saling toleransi dan saling memahami, untuk mengembangkan: a) transformasi diri; b) transformasi sekolah dan proses belajar mengajar, dan; c) transformasi masyarakat.

Pendidikan multikultural menentang semua bentuk asumsi yang belum teruji, bias, dan palsu tentang perbedaan dan persamaan manusia, ia merupakan kritik reflektif dan pencarian terhadap isu-isu tersebut untuk membuka jalan terang bagi komunikasi lintas budaya dan bertindak lebih adil dan konstruktif

agama dan kerukunan:Harmoni "Jurnal Multikultural dan Multireligius." Vol.II .No.5.( Puslitbang Kehidupan Beragama DEPAG RI, Jakarta, 2003), hlm. 15.

${ }^{3}$ Heterogenitas dalam bahasa paling mudah adalah beda jenis, Namun dalam bidang pendidikan diartikan sebagai kesadaran untuk menghargai berbagai jenis budaya, adat, agama, suku dan lain-lain. 
terhadap perbedaan kultural. Karena alasan-alasan praktis dan etis, kini siswa dan guru perlu belajar berkomunikasi, mempelajari hidup dan bekerjasama secara efektik dan damai dengan mereka yang secara kultural berbeda. Maka dengan pendidikan semacam ini kita menginginkan agar siswa atau pelajar dari tingkat sekolah dasar, menengah hingga perguruan tinggi dapat tumbuh dalam suatu dunia yang bebas dari prasangka, bias dan diskriminasi atas nama apapun; agama, gender, ras, warna kulit, kebudayaan, kelas, dan sebagainya untuk mencapai suatu tujuan mereka dan merasakan bahwa apapun yang mereka kehendaki untuk dapat terlaksana dalam kehidupan ini menjadi mungkin. ${ }^{4}$

Ada beberapa pembelajaran yang harus di fokuskan guru agama pada peserta didik sebagaimana yang telah diungkapkan oleh Hatimah, dkk. AdapunTujuanPendidikanMultikulturalantara lain. ${ }^{5}$

\section{Pembelajaran Perdamaian}

Javier Perez (Tilaar: 2000) mengungkapkan bahwa perdamaian harus dimulai dari diri kita masing-masing. Melalui pemikiran yang tenang dan sungguh-sungguh tentang maknanya, maka cara-cara baru dan kreatif dapat ditemukan untuk mengembangkan pengertian, persahabatan dan kerja sama antara semua manusia. Suatu kebudayaan perdamaian di perlukan untuk kehidupan bersama yang bermakna. Di dalam kehidupan yang beragam dalam tata cara pribadi, social dan budaya tentang keberadaan dan kehidupan, maka pemikiran nilai-nilai manusia yang penting dapat mengatasi perbedaan-perbedaan untuk menjamin perdamaian dan solidaritas.

\section{Pembelajaran Hak Asasi Manusia}

Semua hak manusia adalah universal, tak terbagi, interdependen dan saling terkait. Pendidikan adalah alat yang paling efektif untuk pengembangan nilai-nilai yang berhubungan dengan hak-hak asasi manusia. Pendidikan hak-hak asasi manusia haruslah mengembangkan kemampuan untuk menilai kebebasan pemikiran, kata hati dan keyakinan, kemampuan untuk menilai kesamaan, keadilan dan cinta, dan suatu kemauan untuk mengasuh dan melindungi hak-hak

${ }^{4}$ Zakiyuddin Baidhawi, Pendidikan Agama Berwawasan Multikultural (Jakarta: Erlangga, 2005), hlm. 8

${ }^{5}$ Hatimah, dkk, Pendidikan Berwawasan Kemasyarakatan, (Jakarta: Universitas Terbuka, 2007), hlm. 7.19-7.22 
anak, kaum wanita, kaum pekerja, minoritas etnik, kelompok-kelompok yang tidak beruntung.

3. Pembelajaran Demokrasi

Pembelajaran untuk demokrasi pada hakekatnya adalah untuk mengembangkan eksistensi manusia dengan jalan mengilhaminya dalam pengertian martabat dan persamaan, saling mempercayai, toleransi, penghargaan pada kepercayaan dan kebudayaan orang lain, penghormatan pada individu, peran serta aktif dalam semua aspek kehidupan social, kebebasan berekspresi, kepercayaan dan beribadat. Apabila hal-hal tersebut sudah ada, maka dapat digunakan untuk mengembangkan pengambilan keputusan yang efektif, demokratis pada semua tingkatan yang akan mengarah pada kewajaran, keadilan dan perdamaian.

\section{Multikulturalisme dalam Pandangan Agama Islam}

Islam sebagai suatu ajaran tentang kehidupan manusia merupakan suatu pandangan yang tidak dapat diperdebatkan lagi di kalangan kaum muslim. Akan tetapi, bagaimana Islam difahami dan diterapkan oleh pemeluknya dalam kehidupan, dalam kontek inilah, terletak persoalan yang sebenarnya. Karena Islam sebagai ajaran itu satu (tunggal) tetapi polyinterpretable (pemahaman terhadap Islam itu beragam). ${ }^{6}$

Multikulturalisme yang bermakna penghargaan dan pengakuan terhadap budaya lain, secara normatif dapat dibenarkan keberadaannya. Multikulturalisme dalam Islam dapat dirujukkan minimal dari tiga kategori, yakni petama perspektif teologis, kedua perspektif historis dan ketiga perspektif sosiologis. ${ }^{7}$

1. Multikulturalisme dalam Perspektif Teologis

Islam dapat ditemukan dalam banyak ayat-ayat al-Qur'an. Sebagaimana kita ketahui bahwa kemajemukan yang ada di dunia ini adalah sebuah kenyataan yang sudah menjadi sunnatullah (ketentuan Allah). Di dalam al-Qur'an surat al-Hujurat ayat:13 Allah menyebutnya bahwa kemajemukan adalah kehendakknya.

${ }^{6}$ Yusdani. Fiqih Poitik Muslim. (Yogyakarta : Amara Books, 2011), hlm. 276.

${ }^{7}$ A. Eby Hara, Pengalaman Multikulturalisme di Berbagai Negara, dalam "AlWasathiyyah", Vol I, Februari 2006, hlm. 39. 


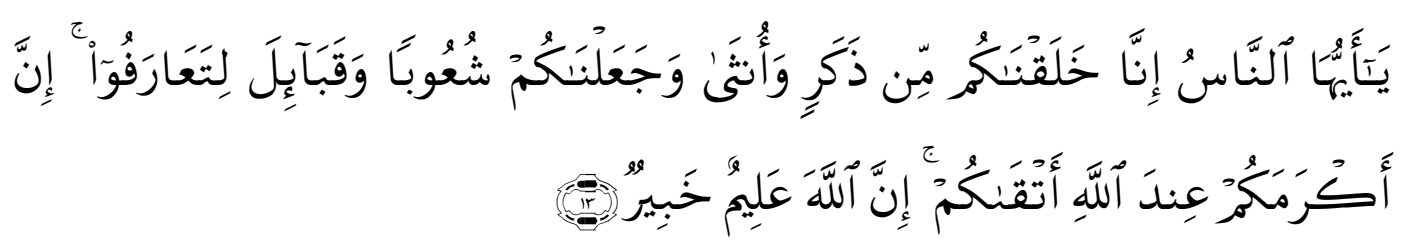

Artinya: "Hai manusia, Sesungguhnya Kami menciptakan kamu dari seorang laki-laki dan seorang perempuan dan menjadikan kamu berbangsa-bangsa dan bersuku-suku supaya kamu saling kenal-mengenal. Sesungguhnya orang yang paling mulia diantara kamu disisi Allah ialah orang yang paling taqwa diantara kamu. Sesungguhnya Allah Maha mengetahui lagi Maha Mengenal". ${ }^{8}$

Abdullah Yusuf Ali dalam buku tafsirnya The Holy Qur'an: Translate and Commentary memberikan komentar bahwa ayat ini tidaklah ditujukan untuk persaudaraan muslim saja, tetapi kepada seluruh umat manusia, karena hakekat keduanya sama.

Dari ayat 13 surat al-Hujurat di atas, sangat tegas bahwa Islam pada dasarnya menganggap sama pada setiap manusia, yakni tercipta dan dilahirkan dari sepasang orang tua mereka (laki-laki dan perempuan), kemudian keterlahiran ini sendiri mempunyai tujuan untuk saling mengenal dan memahami karakter masing-masing kelompok setelah manusia ini menjadi kelompok yang berbeda.

Dalam surat lain, Q.S. ar-Rum ayat 22 Allah berfirman:

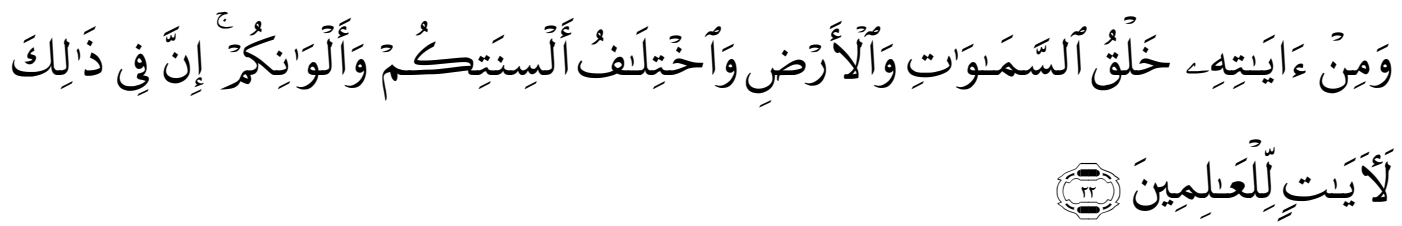

Artinya: "Dan di antara tanda-tanda kekuasaan-Nya ialah menciptakan langit dan bumi dan berlain-lainan bahasamu dan warna kulitmu. Sesungguhnya pada yang demikan itu benar-benar terdapat tanda-tanda bagi orang-orang yang mengetahui"

Ayat ini menerangkan bahwa perbedaan warna kulit, bahasa, dan budaya harus diterima sebagai sesuatu yang positif dan merupakan tanda-tanda dari kebesaran Allah SWT. Untuk itu sikap yang diperlukan bagi seorang muslim dalam merespon kemajemukan dan perbedaan adalah dengan memandangnya

${ }^{8}$ Depatemen Agama RI, Al-Qur'an danTerjemahan, hlm. 49. 
secara positif dan optimis. Dengannya seorang muslim akan mampu bertindak dengan bijak dan selalu termotivasi untuk berbuat baik

1. Multikulturalisme dalam Perspektif Historis

Dalam perspektif ini dapat dirujuk langsung oleh sistem kenegaraan yang diterapkan Nabi Muhammad SAW dengan Piagam Madinahnya. Piagam Madinah ini adalah konsesi atas Hijrah Nabi Muhammad SAW pada tahun 622 Masehi yang menemukan kondisi sosiologis Madinah berbeda dengan di Makkah. Sebelum hijrah, Nabi memulainya dengan membuat Perjanjian Aqabah (bai'at al'aqabah). Baiat adalah transaksi, seperti jual beli. Artinya, dalam perjanjian ada transaksi seperti jual dagang, berkompromi sampai pada yang disepakati. Kalau model baiat sekarang dipaksakan oleh guru dan secara membabi buta. Dahulu baiat didasarkan pada konsensus dan bargaining untuk saling mendapatkan. Dalam Perjanjian Aqabah pada tahun 621 M disebutkan bahwa orang-orang Madinah akan bersedia menerima Nabi dan sahabatnya untuk berhijrah ke Madinah dengan jaminan Nabi bisa dipercaya menjadi rekonsiliator untuk menegakkan konflik kesukuan (tribal) yang tidak ada habisnya.

Karena semua menjadi bagian dari konflik, maka tidak ada yang memiliki otoritas untuk menyelesaikan. Seperti halnya yang terjadi di Papua, antar suku sudah menjadi bagian konflik, tidak ada yang bisa menyelesaikan. Dalam perspektif antropologi perlu adanya outsider essential yang akan menyelesaikan konflik-konflik itu. Dan kabilah-kabilah di Madinah menerima Nabi tetapi dengan jaminan Nabi harus memerankan diri sebagai hakim yang adil dan bisa menengahi konflik antar suku karena mereka juga lelah.

Orang-orang yang terikat dalam perjanjian tersebut disebut sebagai "umat". Umat adalah siapapun yang ikut dalam semua kesepakatan atau perjanjian Piagam Madinah, termasuk di dalamnya adalah Nabi. Siapapun yang diserang akan dibela dan siapapun yang berkhianat akan diserang. Karena itu, pada zaman Nabi tidak ada yang menyerang kecuali dia berkhianat. Piagam Madinah disusun dalam posisi yang sama, hidup, kehormatan dan kehendak mencapai kebahagiaan menjadi jaminan dalam piagam tersebut. ${ }^{9}$

9 Yudi Latif, Tafsir Sosiologis atas Piagam Madinah, dalam "Islam, HAM, dan Keindonesiaan Refleksi dan Agenda Aksi untuk Pendidikan Agama", di MAARIF Institute for Culture and Humanity, Jakarta, 23 Mei 2007. 


\section{Multikulturalisme dalam Perspektif Sosiologis}

Prespektif sosiologis intern umat Islam sendiri. Hal ini dapat dilihat dalam praktek keberagamaan umat Islam di seantero dunia Islam. Secara internal umat Islam memiliki keanekaragaman madzhab fiqih, tasawuf dan kalam. Dalam bidang fiqih umat Islam Indonesia mengenal adanya madzhab lima, dari Imam Syafii dengan qauljadid dan qadimnya, Imam Hanafi, Hambali, Abu Hanifah dan Imam Ja'far. Begitu juga dalam ilmu kalam, Imam al-Asy'ari, dan Maturidy disebut sebagai penggagas Ahlussunnah (Sunni), Wasil bin Atho' dengan mu'tazilahnya, khawarij, murjiah juga ada Syi'ah dan para pendukung Imam Ali dibelakangnya.

Kemajemukan intern umat Islam juga ditemukan dalam praktek pengelompokan sosial, politik kepartaian serta model pendidikannya. Dinasti dan kekhalifahan yang pernah ada dalam sejarah Islam seperti Dinasti Mughal, Fathimiyah, Abasiah dan terakhir dinasti Turki Usmani adalah contoh konkret tentang keragaman yang ada dalam Islam. Dari sudut multikulturalisme internal ini, pluralisme identitas cultural keagamaan bagi masyarakat muslim, bukanlah menjadi sekedar fakta, lebih dari itu, multikulturalisme telah menjadi semangat, sikap hidup dan pendekatan dalam menjalani kehidupan dengan orang lain.

Secara ideal tidak ada masalah dalam ketentuan normatif agama, semua berujung pada kebaikan universal, baik dalam relasi vertikal antara manusia dengan Allah (hablun min-Allah), maupun dalam relasi horizontal sesama manusia (hablun min-annas), baik di dunia maupun di akherat kelak. Namun secara faktual, tidak jarang, agama justru menjadi dalih untuk memicu konflik, atau minimal menjadi sumber pembenaran atas berlangsungnya sengketa berdarah. Sampai-sampai sebagian sosiolog berpendapat, bahwa agama disamping berfungsi sebagai pemersatu, juga pemecah belah, seperti misalnya faktor fanatisme agama yang menjadi pemicu terjadinya perang salib (yang banyak merugikan dua belah pihak). ${ }^{10}$

\section{Kurikulum Pendidikan Agama Islam Berbasis Multikultural}

Pendidikan adalah salah satu bentuk perwujudan kebudayaan manusia yang dinamis dan sarat perkembangan, karena itu perubahan atau perkembangan

${ }^{10}$ Muhammad Yahya. Pendidikan Islam Pluralis dan Multikultural. (Makassar : Jurnal Lentera Pendidikan, Vol 13 No. 2 Desember 2010), hlm. 3. 
pendidikan adalah hal yang memang seharusnya terjadi sejalan dengan perubahan budaya kehidupan. Perbaikan pendidikan ini mengandung konsekuensi akan adanya penyempurnaan atau perbaikan kurikulum pendidikan agama Islam. Hal ini dimaksudkan untuk mengantisipasi kebutuhan dan tantangan masa depan dengan diselaraskan terhadap perkembangan kebutuhan dunia usaha atau industri, perkembangan dunia kerja, serta perkembangan ilmu pengetahuan, teknologi, dan seni. Konsep yang sekarang banyak diwacanakan oleh banyak ahli adalah kurikulum pendidikan berbasis pluralisme.

Pendidikan Islam berbasis pluralisme mempunyai beberapa karakter sebagai berikut:

1. Pendidikan Islam harus mempunyai karakter sebagai lembaga pendidikan umum yang bercirikan Islam.

2. Pendidikan Islam juga harus mempunyai karakter sebagai pendidikan yang berbasis pada pluralitas..

3. Pendidikan Islam harus mempunyai karakter sebagai lembaga pendidikan yang menghidupkan sistem demokrasi dalam pendidikan.

Untuk merealisasikan cita-cita pendidikan yang mencerdaskan seperti tersebut, lembaga pendidikan Islam perlu menerapkan sistem pengajaran yang berorientasi pada penanaman kesadaran pluralisme dalam kehidupan. Adapun beberapa program pendidikan yang sangat strategis dalam menumbuhkan kesadaran pluralisme adalah: pendidikan sekolah harus membekali para mahasiswa atau peserta didik dengan kerangka (frame work) yang memungkinkannya menyusun dan memahami pengetahuan yang diperoleh dari lingkunganya (UNESCO, 1981). Karena masyarakat kita majemuk, maka kurikulum PAI yang ideal adalah kurikulum yang dapat menunjang proses siswa menjadi manusia yang demokratis, pluralis dan menekankan penghayatan hidup serta refleksi untuk menjadi manusia yang utuh, yaitu generasi muda yang tidak hanya pandai tetapi juga bermoral dan etis, dapat hidup dalam suasana demokratis satu dengan lain, dan menghormati hak orang lain.

Ada empat hal yang perlu diperhatikan guru dalam mengembangkan kurikulum sebagai proses ini, yaitu; (1) posisi siswa sebagai subjek dalam belajar, (2) cara belajar siswa yang ditentukan oleh latar belakang budayanya, (3) lingkungan budaya mayoritas masyarakat dan pribadi siswa adalah entry 
behaviour kultur siswa, (4) lingkungan budaya siswa adalah sumber belajar (Hamid, op cit: 522). Dalam konteks deskriptif ini, kurikulum pendidikan mestilah mencakup subjek seperti: toleransi, tema-tema tentang perbedaan ethnokultural dan agama: bahaya diskriminasi: penyelesaian konflik dan mediasi: HAM; demokrasi dan pluralitas; kemanusiaan universal dan subjek-subjek lain yang relevan.

Bentuk kurikulum dalam pendidikan agama Islam hendaknya tidak lagi ditujukan pada siswa secara individu menurut agama yang dianutnya, melainkan secara kolektif dan berdasarkan kepentingan bersama. Bila selama ini setiap siswa memperoleh pelajaran agama sesuai dengan agamanya, maka diusulkan agar lebih baik bila setiap siswa SLTP-PT memperoleh materi agama yang sama, yaitu berisi tentang sejarah pertumbuhan semua agama yang berkembang di Indonesia. Sedangkan untuk SD diganti dengan pendidikan budi pekerti yang lebih menanamkan nilai-nilai moral kemanusiaan dan kebaikan secara universal. Dengan materi seperti itu, di samping siswa dapat menentukan agamanya sendiri (bukan berdasarkan keturunan), juga dapat belajar memahami pluralitas berdasarkan kritisnya, mengajarkan keterbukaan, toleran, dan tidak eklusif, tapi inklusif. $^{11}$

Dan perlu diketahui, suatu kurikulum tidak dapat diimplementasikan tanpa adanya keterlibatan, pembuatan dan kerjasama secara langsung antara para pembuat kurikulum, penulis text book dan guru.

Langkah-langkah yang perlu diperhatikan untuk mengembangkan kurikulum PAI berbasis pluralisme di Indonesia, adalah sebagai berikut:

1. Mengubah filosofi kurikulum dari yang berlaku seragam kepada filosofi yang lebih sesuai dengan tujuan, misi, dan fungsi setiap jenjang pendidikan dan unit pendidikan.

2. Kurikulum harus yang berisikan fakta, teori, generalisasi kepada pengertian yang mencakup pula nilai, moral, prosedur, dan ketrampilan yang harus dimiliki generasi muda.

3. Teori belajar yang digunakan dalam kurikulum masa depan yang memperhatikan keragaman sosial, budaya, ekonomi, dan politik.

\footnotetext{
${ }^{11}$ Darmaningtyas, Pendidikan Pada Dan Setelah Krisis, (Yogyakarta: 1999), hlm. 165.
} 
4. Proses belajar yang dikembangkan harus berdasarkan proses yang memiliki tingkat isomorphism yang tinggi dengan kenyataan sosial. Artinya, proses belajar yang mengandalkan siswa belajar individualistis harus ditinggalkan dan diganti dengan cara belajar berkelompok dan bersaing secara kelompok dalam suatu situasi positif.

5. Evaluasi yang digunakan haruslah meliputi keseluruhan aspek kemampuan dan kepribadian peserta didik, penggunaan alternatif assesment (portfolio, catatan, observasi, wawancara) dapat digunakan.

Di samping perlunya memperhatikan langkah-langkah itu, untuk menuju sebuah PAI yang menghargai pluralisme, sebenarnya selain aspek kurikulum yang harus didesain, sebagaimana telah penulis uraikan, aspek pendekatan dan pengajaran harus pula di perhatikan. Pola-pola lama dalam pendekatan atau pengajaran agama harus segera dirubah dengan model baru yang lebih mengalir dan komunikatif. Aspek perbedaan harus menjadi titik tekan dari setiap pendidik.

\section{Mewujudkan Pembelajaran Multikultural Dalam Pendidikan Agama Islam}

Menurut Savage dan Amstrong, pembelajaran berbasis multikultural berusaha memberdayakan siswa untuk mengembangkan rasa hormat kepada orang yang berbeda budaya, memberi kesempatan untuk bekerja bersama dengan orang atau kelompok orang yang berbeda etnis atau rasnya secara langsung. ${ }^{12}$ Pendidikan multikultural juga membantu siswa untuk mengakui ketepatan dari pandangan-pandangan budaya yang beragam, membantu siswa dalam mengembangkan kebanggaan terhadap warisan budaya mereka, menyadarkan siswa bahwa konflik nilai sering menjadi penyebab konflik antar kelompok masyarakat. Pendidikan multicultural lebih lanjut diselenggarakan dalam upaya mengembangkan kemampuan siswa dalam memandang kehidupan dari berbagai perspektif budaya yang berbeda dengan budaya yang mereka miliki, dan bersikap positif terhadap perbedaan budaya, ras, dan etnis. ${ }^{13}$

Secara global, James A. Banks mengidentifikasi ada lima dimensi pendidikan multikultural yang diperkirakan dapat membantu guru dalam

\footnotetext{
12 T.V Savage,\& D.G. Armstrong, Effective Teaching in Elementary Social Studies, Ohio: Prentice, 1996.

13 P.J. Farris,\& S.M. Cooper, Elementary Social Studies: a Whole language Approach, Iowa: Brown\&Benchmark Publishers, 1994.
} 
mengimplementasikan beberapa program yang mampu merespon terhadap perbedaan pelajar (siswa), yaitu:

\section{Dimensi integrasi isi/materi (content integration)}

Dimensi ini digunakan oleh guru untuk memberikan keterangan dengan 'poin kunci' pembelajaran dengan merefleksi materi yang berbeda-beda. Secara khusus, para guru menggabungkan kandungan materi pembelajaran ke dalam kurikulum dengan beberapa cara pandang yang beragam.

2. Dimensi konstruksi pengetahuan (knowledgeconstruction)

Suatu dimensi dimana para guru membantu siswa untuk memahami beberapa perspektif dan merumuskan kesimpulan yang dipengaruhi oleh disiplin pengetahuan yang mereka miliki. Dimensi ini juga berhubungan dengan pemahaman para pelajar terhadap perubahan pengetahuan yang ada pada diri mereka sendiri.

3. Dimensi pengurangan prasangka (prejudice ruduction)

Guru melakukan banyak usaha untuk membantu siswa dalam mengembangkan perilaku positif tentang perbedaan kelompok. Sebagai contoh, ketika anak-anak masuk sekolah dengan perilaku negatif dan memiliki kesalahpahaman terhadap ras atau etnik yang berbeda dan kelompok etnik lainnya, pendidikan dapat membantu siswa mengembangkan perilaku intergroup yang lebih positif, penyediaan kondisi yang mapan dan pasti.

4. Dimensi pendidikan yang sama/adil (equitablepedagogy)

Dimensi ini memperhatikan cara-cara dalam mengubah fasilitas pembelajaran sehingga mempermudah pencapaian hasil belajar pada sejumlah siswa dari berbagai kelompok. Strategi dan aktivitas belajar yang dapat digunakan sebagai upaya memperlakukan pendidikan secara adil, antara lain dengan bentuk kerjasama (cooperatvelearning), dan bukan dengan cara-cara yang kompetitif (competitionlearning).

5. Dimensi pemberdayaan budaya sekolah dan struktur sosial (empoweringschoolculture and socialstructure)

Dimensi ini penting dalam memperdayakan budaya siswa yang dibawa ke sekolah yang berasal dari kelompok yang berbeda. Di samping itu, dapat digunakan untuk menyusun struktur sosial (sekolah) yang memanfaatkan potensi budaya siswa yang beranekaragam sebagai karakteristik struktur sekolah 
setempat, misalnya berkaitan dengan praktik kelompok, iklim sosial, latihanlatihan, partisipasi ekstra kurikuler dan penghargaan staff dalam merespon berbagai perbedaan yang ada di sekolah.

Mengenai materi pendidikan agama Islam sendiri, menurut Z. Arifin Nurdin, gagasan multikultural bukanlah sesuatu yang sulit ataupun baru. Setidaknya ada tiga alasan untuk itu. Pertama, bahwa Islam mengajarkan menghormati dan mengakui keberadaan orang lain. Kedua, konsep persaudaraan Islam tidak hanya terbatas pada satu sekte atau golongan saja. Ketiga, dalam pandangan Islam bahwa nilai tertinggi seorang hamba adalah terletak pada integralitas taqwa dan kedekatannya dengan Tuhan.

Untuk merancang strategi hubungan multicultural dan etnik dalam sekolah dapat digolongkan kepada dua yakni pengalaman pribadi dan pengajaran yang dilakukan oleh guru. Adapun dalam bentuk pengajaran adalah sebagai berikut: pertama guru harus sadar akan keragaman etnik siswa, tidak bisa dalam mendidik, kedua, bahan kurikulum dan pengajaran seharusnya refleksi keragaman etnik dan ketiga adalah bahan kurikulum dituliskan dalam bahasa daerah / etnik yang berbeda.

Apabila pengajaran multikultural dapat dilakukan dalam sekolah baik umum maupun agama hasilnya akan melahirkan peradaban yang juga melahirkan toleransi, demokrasi, kebajikan, tolong menolong, tenggang rasa, keadilan, keindahan, keharmonisan dan nilai-nilai kemanusiaan lainnya. Intinya gagasan dan rancangan sekolah yang berbasis multikultural adalah sebuah keniscayaan dengan catatan bahwa kehadirannya tidak mengaburkan dan atau menciptakan ketidakpastian jati diri para kelompok yang ada.

Menurut Samsul Ma'arif, kurikulum pendidikan Islam setidaknya harus berisi beberapa muatan multikultural. Samsul mendeskripsikan solusinya ke dalam lima pokok muatan kurikulumantara lain:

a. Pendidikan agama seperti fiqih, tafsir tidak harus bersifat linier, namun menggunakan pendekatan muqaron. Ini menjadi sangat penting, karena anak tidak hanya dibekali pengetahuan atau pemahaman tentang ketentuan hukum dalam fiqih atau makna ayat yang tunggal, namun juga diberikan pandangan yang berbeda. Tentunya, bukan sekedar mengetahui yang berbeda, namun juga diberikan pengetahuan tentang mengapa bisa berbeda. 
b. Untuk mengembangkan kecerdasan sosial, siswa juga harus diberikan pendidikan lintas agama. Hal ini dapat dilakukan dengan program dialog antar agama yang perlu diselenggarakan oleh lembaga pendidikan Islam. Program ini menjadi sangat strategis, khususnya untuk memberikan pemahaman kepada siswa bahwa ternyata puasa itu juga menjadi ajaran saudara-saudara kita yang beragama Budha.

c. Untuk memahami realitas perbedaan dalam beragama, lembaga-lembaga pendidikan Islam bukan hanya sekedar menyelenggarakan dialog antar agama, namun juga menyelenggarakan program road show lintas agama. Program road show lintas agama ini adalah program nyata untuk menanamkan kepedulian dan solidaritas terhadap komunitas agama lain.

d. Untuk menanamkan kesadaran spiritual, pendidikan Islam perlu menyelenggarakan program seperti spiritual work camp (SWC), hal ini bisa dilakukan dengan cara mengirimkan siswa untuk ikut dalam sebuah keluarga selama beberapa hari, termasuk kemungkinan ikut pada keluarga yang berbeda agama.

e. Pada bulan Ramadhan, adalah bulan yang sangat strategis untuk menumbuhkan kepekaaan sosial pada anak didik. Dengan menyelenggarakan "program sahur on the road”, misalnya. Karena dengan program ini, dapat dirancang sahur bersama antara siswa dengan anak-anak jalanan. Program ini juga memberikan manfaat langsung kepada siswa untuk menumbuhkan sikap kepekaan sosial, terutama pada orang-orang di sekitarnya yang kurang mampu.

\section{KESIMPULAN}

Sesuai dengan tujuan pendidikan sendiri yang menghendaki adanya perubahan perilaku dan sikap serta kualitas seseorang, maka pengajaran harus berlangsung sedemikian rupa sehingga tidak sekedar memberi informasi atau pengetahuan melainkan harus menyentuh hati, dan mendorong hasrat peserta didik untuk bisa mengambil keputusan berubah, dan mempraktekkannya langsung sepanjang kehidupan manusia.

Mengambil prinsip pendidikan sepanjang hayat (long life education), Pendidikan agama Islam juga harus mampu menjiwai pada tingkat kesadaran 
paling dalam pada diri siswa. Dengan demikian, di samping bertujuan untuk memperteguh keyakinan pada agamanya, pendidikan Agama Islam berbasis multicultural juga harus diorientasikan untuk menanamkan empati, simpati dan solidaritas terhadap sesama, menjadikannya sebagai bagian yang tidak terpisahkan dari perilaku siswa keseharian terutama terkait dengan kemajemukan kultur (multicultural) yang ada. Maka dalam hal ini, semua materi pelajaran yang diajarkan tentunya harus menyentuh dan bermuatan multikulturalitas. Dan dari sinilah urgensi multikultural bisa diajar dan dijalankan.

\section{DAFTAR PUSTAKA}

Hammond. Washington D.C.: American Educational Research Association,1993.

Binawah, Al. Andang L., Penyempitan kaebebasan Beragama, Yogyakarta, Basis, Januari-Februari 2004.

Hara, A. Eby, Pengalamn Multikulturalisme di Berbagai Negara, dalam "Al -Wasathiyyah", Vol I, februari 2006. 
Hasan, Hamid, S., (2000), "Pendekatan Multikultural Untuk Penyempurnaan Kurikulum Nasional”, dalam Jurnal Pendidikan dan Kebudayaan, Jakarta, Edisi Bulan Januari-November.

Hasan, Hamid, S., (2000), "Pendekatan Multikultural Untuk Penyempurnaan Kurikulum Nasional”, dalam Jurnal Pendidikan dan Kebudayaan, Jakarta, Edisi Bulan Januari-November.

Ma'arif, Syamsul, Islam Dan Pendidikan Pluralisme, (Menampilkan Wajah Islam Toleran Melalui Kurikulum PAI Berbasis Kemajemukan), makalah disampaikan dalam Annual Conference Kajian Islam Di Lembang Bandung Tanggal 26-30 November Tahun 2006.

Suparlan, Parsudi, Menuju Masyarakat Indonesia yang Multikultural, Simposium Internasional Bali, Jurnal Antropologi Indonesia, Denpasar Bali, 16-21 Juli 2002.

Tafsir Ahmad, Metodologi Pengajaran Agama Islam, Bandung, Remaja Rosdakarya, 2002. 